\title{
the pleating of history
}

\author{
Weaving the Threads of Nationhood \\ MARTIN BALL
}

All I have is a voice

To undo the folded lie.

WH Auden, 'September 1, 1939'

\section{- Folding}

The metaphors of history are numberless. They range from Voltaire's 'tableau of crimes and misfortunes' to de Tocqueville's 'gallery of pictures', from Dionysius's axiom that history is 'philosophy from examples' to the jocular truism that it is simply 'what you can remember. ${ }^{1}$ History is all these things and more besides, and the metaphors multiply with each new theory and interpretation of Clio's domain.

The most fashionable metaphor of recent years has the quality of also being the simplest: history is a text-or, to further abstract the predicate, history is text. This construction owes much to the advent of the 'linguistic turn', which drew attention to the role of language in epistemology, and the function of narrative in historiography. And whether one regards history as 'what actually happened', or the record of what happened, the metaphor remains. As Hayden White says in the preface to Metahistory: 'I treat the historical work as what it most manifestly is: a verbal structure in the form of a narrative prose discourse'-in other words, a text. ${ }^{2}$

As any etymologist knows, the word 'text' is derived from the past participle of the Latin verb texere, to weave. Text is therefore something that is 'woven'. It's a persuasive metaphor, to imagine writing in terms of the warp and weft of ideas and words, of 
narrative threads woven together to become a piece of fabric. We can see this metaphor at work in the language of Michel de Certeau's question, 'What do historians fabricate when they "make history"? ’3 De Certeau answers his question by reference to place, practice, and text; we can say simply that what historians do is 'fabricate' text, they make a kind of fabric.

The idea of history as fabric brings together a whole different set of tropes, not just of weaving, but of the very materiality of fabric. Does the fabric have a nap, or a pattern? Is it cut with the grain, or on the bias? What of its folds, its seams? All these qualities of fabric have application in the interpretation of history, and some of these images are already familiar in historical discourse. For example, Walter Benjamin argues in his 'Theses on the Philosophy of History' that the role of the historical materialist is 'to brush history against the grain'-this recalls the quality of a fabric with a nap, such as velvet or corduroy, which changes appearance and texture depending on its direction. Similarly, GR Elton devotes a chapter of The Practice of History to the role of 'patterns and bias' - a pattern is ruptured when it is cut and joined, and a fabric that is cut 'on the bias' creates a different shape as it falls, giving it body and movement. ${ }^{4}$

Thinking of history as fabric gives it a sense of physical materiality, as something textured yet pliable, something that can be coloured by dye, that can be rent into shreds, be cut and sewn, unpicked and restitched. It is also something that can be folded, to bring together times and places that are otherwise separate and apart. Gilles Deleuze dedicates a whole book to the philosophical significance of folding: 'the fold affects all materials ... it becomes a form of expression'. ${ }^{5}$ Folding creates an artificial sense of relations, and a double fold creates a new visible pattern that does not necessarily exist in the original fabric. This is the case at a physical level, such as the way the back cover of a Mad magazine can be folded to produce an unexpected image. But it also extends to the metaphysical, such as when Mrs Who explains the 'tesseract' in A Wrinkle in Time, by folding parts of a skirt together to shorten the distance of time and space. ${ }^{6}$

Returning then to De Certeau's question, we can say that what is fabricated in making history is a fold in time and space. When we make folds we bring together events, people and places which might otherwise be unrelated, in order to make a story. And when a historian polishes this story into a text, it is akin to ironing the folds into pleats. Pleats can be of differing type and magnitude of course. A box pleat makes a feature of the folding process, whereas an inverted pleat hides the folds behind a smooth surface. It's easy to see how these metaphors can be applied to differing interpretations of history, for example the colonisation of Tasmania: one historian foregrounds the issue of violence, another tucks it neatly out of sight. But each one makes folds and seams in narratives and archives; each one pleats the fabric of history. 


\section{- DigGING}

In the proem to Henry Handel Richardson's Australia Felix a miner is buried alive in a shaft in the Gravel Pits at Ballarat:

The digger fell forward on his face, his ribs jammed across his pick, his arms pinned to his sides, nose and mouth pressed into the sticky mud as into a mask; and over his defenceless body, with a roar that burst his ear-drums, broke stupendous masses of earth. ${ }^{7}$

This scene presents the double vision of a man at the mercy of the elemental soil and clay, and of the defiled earth exacting revenge for its rape and exploitation by the miner. At a structural level this passage introduces the themes of death and burial that will frame Richardson's trilogy The Fortunes of Richard Mahony. It also invokes what might be called the national topos of 'death by landscape', an image that stalks the Australian imagination from Leichhardt and Voss to Azaria Chamberlain, from Picnic at Hanging Rock to Death of a River Guide.

But if we make a fold between the subject of the novel and the year of its publication in 1917, a further reading suggests itself_-again surrounding the discourses of nation and the sacrifice of the male subject, but a long way from the goldfields of colonial Ballarat. Rereading the paragraph against the moment of its publication, Richardson's narrative becomes an uncanny mimesis of the trenches of the Great War. A 'digger' is interred in the mud amid a roaring hail of vomiting earth. Here is a gripping and accurate description of a soldier being hit by artillery, of being buried in the mire under Wilfred Owen's 'shrill, demented choirs of wailing shells' ${ }^{8}$ When the later, transposed meaning of the Anzac 'digger' is considered, the picture is complete. The striking parallels between miner and soldier demonstrate how easily images and stories of one time and place can be applied to another, and made to fit a pattern.

By visiting various sites of national imagery, Richardson's novel generates some expectation about its engagement with the 'narrative of nation'. But as Philip Mead argues, The Fortunes of Richard Mahony does not simply symbolise or metaphorise the birth of the nation; rather, the novel suggests there is no possible reconciliation between subject and nation. ${ }^{9}$ Certainly any homology between the diggers at Eureka and the emergent Australian democracy has miscarried in the national consciousness (notwithstanding the momentum of the Eureka 150 celebrations). Meanwhile that other digger, the Anzac, has become fused inseparably with national identity, and Gallipoli has become the seam around which the history of Australian nationhood is shaped and told. 
The way the stories of Australian nationhood coalesce in the signifier 'Gallipoli' are a perfect example of what Gananath Obeyesekere calls a 'myth model'. Obeyesekere defines a myth model as a paradigmatic myth that serves as a model for mythmaking: 'an underlying set of ideas (or cluster of mythemes) employed in a variety of narrative forms'. ${ }^{10}$ The motivation for this term is to show that mythopœisis is not restricted to socalled savage thought, but is 'equally prolific' in modern societies. Obeyesekere introduces this idea in the context of his debate with Marshall Sahlins about the death of Captain Cook, and whether the Hawaiians regarded Cook as a god or a man. There are strengths and weaknesses on both sides of this debate, but the main advantage of Obeyesekere's approach is that it moves the question of 'myth' from one of ontology and epistemology (for example, how savages think) to one of narratology: that is, how we tell stories.

Obeyesekere suggests that a myth model is the form of a myth articulated in narrative genres according to the ideologies and technologies apposite to the society at the time. As historical conditions change, the form of the myth model is modulated through prevailing genres, though the narratives remain 'isomorphic' with previous manifestations. It is easy to see how mythemes can be inserted or 'embroidered' into narratives, and thus how myth models can flourish in forms such as fiction, biography and history. And as I will discuss below, the example of Gallipoli demonstrates the particular affinity of myth models to the narratives of nationhood.

\section{- DYING}

Most recent theorists writing on the subject 'nations, nationhood and nationalism' concur that the contemporary nation is a relatively modern phenomenon, which gained momentum in the nineteenth century and blossomed fully in the twentieth. In 1882 Ernest Renan can say with confidence that 'Nations are a new feature in history'. A century later and little has changed. Eric Hobsbawm still writes on the nation as a 'novelty', Tom Nairn declares nationalism to be the 'pathology of modern developmental history', and Benedict Anderson sees the idea of the nation as quintessentially contemporary: 'Nation-ness is the most universally legitimate value in the political life of our time.' ${ }^{11}$

The end of the Great War affords some of the clearest examples of this outpouring of 'nation-ness' and national identity. Apart from the issue of reparations, the Treaty of Versailles is characterised particularly by the political foundation and re-formation of numerous states (many of which already considered themselves 'nations'). Says Hobsbawm, 'If there was a moment when the nineteenth-century "principle of nationality" triumphed it was at the end of World War I. ${ }^{12}$ The correlative for Anzac and 
nationhood in Australia is that the historical event of Gallipoli is coeval with a unique and particular moment in the international development of the concept of the nation. This is crucial in understanding what sort of myth models were active in the national imagination in the decades surrounding Federation and Gallipoli.

There have been many hypotheses on the whys and wherefores of the rise in nations and nationalism. Reasons are sought and found in any number of historical developments; such as the industrial revolution, advances in literacy, decolonisation, universal suffrage, and so on. Political and historical models have mapped and traced the changes, offering insights and explanations on the differences between nation and state, between race and nation. In recent years, however, cultural theories have garnered the most attention, most notably that of Benedict Anderson.

Anderson's thesis of the nation as an 'imagined community' is well known and needs little explanation here-though it will be useful to retrace some of the background to his argument. Anderson maintains that the morphology of the modern nation has been brought about by 'three fundamental cultural conceptions', which descended from antiquity, but began to disintegrate from the time of the Renaissance onwards. The first and most important of these was the development of print-capitalism, which helped lift the veil of illiteracy and broke down the power mystique of script-languages. The second was the evaporation of the divine right of kings and the accordant centripetal power of an unaccountable monarch. The third was the metamorphosis in temporal understanding, which encouraged the idea of linear time, of progress 'driving a harsh wedge between cosmology and history'. The first two of these are relatively unremarkable; they are wellestablished phenomena and Anderson applies them practically and profitably to his thesis. The third point on the changing apprehension of time is more adventurous, and more problematic-I shall return to this below.

The extraordinary influence of Anderson's formulation is no doubt due in part to its felicitous verbal style. The phrase 'imagined community' has proven immensely seductive, yet its ease of currency hides many of the more disturbing aspects it assumes. The first problem is what appears to be an implied homogeneity. How can a body as necessarily large and diverse as a nation-even the most monolingual, monocultural nation—be imagined as a single community? Anderson offers a number of reasons why and how this is so, beginning with language. Looking at the origins of national consciousness he traces developments in printing, the role of colonial lingua francas, of creolisation, and especially the 'philological-lexicological revolution' of the late nineteenth century. He considers the waning of script-languages belonging to exclusive power elites, and the corresponding rise of vernacular languages and indigenous literatures. He examines the status of French and German in Alsace-Lorraine, the orthographical rupture between Croatian and 
Serbian, and the nationalising of the Tuscan dialect in unified Italy. The climax of Anderson's focus on language is his dictum that the nation is 'conceived in language, not in blood'. ${ }^{13}$

In Australia things were different. Colonisation nationalised the whole continent making borders meaningless, and the tidal wave of English effectively erased Aboriginal languages as a threat to the dominant Anglophile culture. There was rampant xenophobia, however, and language policy was harnessed as a prophylactic against foreign contamination. The first law passed by the new federal government in 1901 was the codification of the White Australia Policy, which enshrined an immigration policy that was overtly racist not just in practice but in name. The act functioned by the application of a farcical principle, but it gave immigration officials a linguistic mechanism by which they could reject anyone, and thus keep Australia white and British.

The use of language in such a political fashion is testament to its national importance. But in reality it was blood, the martial underbelly to Anderson's phrase, that quickened Australian nationalism more. At a Federation banquet during the Premiers' Conference in Melbourne in 1890 Henry Parkes drew a colourful metaphor for the assembled guests to see the links between Britain and the Australasian colonies: 'A crimson thread of kinship runs through us all'. ${ }^{14}$ The original crimson thread was a red strand twined into the ropes of the Royal Navy, but it was the haematic dimension of the metaphor that caught the imagination. Blood was something dear to everyone, and British blood was what kept Australia united.

The importance of blood to the national imagining runs on two levels. There are the blood lines of racial strength and purity; and there is the blood of sacrifice and martyrdom. Lawson foresaw 'blood on the wattle', and its purifying effect. DH Lawrence captured something similar in Kangaroo, where Somers remarks that, 'somebody will have to water Australia with their blood before it's a real man's country. The soil, the very plants seem to be waiting for it." 15 This unsettling passage has generated much comment, and invites criticism from a number of quarters; not least in relation to its blindness to armed conflict between settlers and Aborigines. But whatever Lawrence wanted to say about Australia, he was right to draw a link between blood, masculinity, vegetal health and the nation. These, it should be noted, are precisely the same topoi of James Frazer's thesis in The Golden Bough, which influenced so many of Lawrence's generation.

In further highlighting the role of language in imagining the nation, Anderson suggests that national anthems and songs afford opportunities for community afflux: 'Singing the Marseillaise, Waltzing Matilda, and Indonesia Raya provide occasions for unisonality, for the echoed physical realization of the imagined community'. ${ }^{16}$ The Anzac myth provides its own example of unisonance in the intoning of the verses from Binyon's ode For the Fallen. 
It happens each year at the Dawn Service; it happens everyday at $6 \mathrm{pm}$ in the Leagues Clubs, as gamblers and machines together fall silent in a moment of supreme bathos. Even here, though, blood has insinuated its way into the linguistic unisonance, and the sanctity of that spilt blood generally stifles dissent. Here, through the awesome motivating power of war, the unified 'imagined community' becomes fully flesh.

Wars offer the greatest chance for a centripetal concentration of nationalistic imagining. And in the typical myopia of nationalism, it is not what happens to the enemy that affects the imagination, but what happens reflexively to the nation. It's not about killing the other, it's about sacrificing the self. As Anderson observes: 'the great wars of this century are extraordinary not so much in the unprecedented scale on which they permitted people to kill, as in the colossal numbers persuaded to lay down their lives'. ${ }^{17}$ The reasoning, he suggests, is that 'dying for one's country assumes a moral grandeur' above any sacrifice to a mere organisation. But there is a strong whiff of Paul Fussell's 'high diction' in Anderson's use of the sentimental phrase 'laying down one's life'. Equally terrible is indeed the reverse, that nationalism or patriotism enabled so many men to overthrow their normal moral code and kill, all in the name of their country. Gopal Balakrishnan argues that the relationship of war to the pathos of national identity is only fitfully addressed by Anderson, who is 'no doubt discomfited by its implications'. He sees Anderson's suggestion that nations are conceived in language, not in blood, as a 'hopeful formulation' that is too optimistic. Balakrishnan concludes: 'Without the possibility of sacrifice it is doubtful whether the nation evokes the affective peaks of collective belonging that Anderson attributes to the national imagination. ${ }^{18}$ Nationalism is thus likened to a seed that requires incubation, and that heat is provided not in the temperance of peace but in the crucible of war.

Looking at the legacy of military history that underpins the national ideologies of so many nations, Michael Howard asks 'Could a nation really be born without a war?'19 In Australia Henry Parkes had hoped so. At his speech at Tenterfield in November 1889, Parkes suggested it was time the six colonies in Australia come together to form one nation. ${ }^{20}$ After all, he said, Australia now had as many inhabitants as did the USA when they had become an independent nation, and what they had achieved, Australia could too. Parkes spurred his audience to consider that 'surely what the Americans had done by war, the Australians could bring about by peace'. The eventual answer to Parkes's rhetoric would be both yes and no. Politically, Australia would become a nation in 1901, through a peaceful and very democratic process. But imaginatively and spiritually, the nation waited to be consummated by the great narrative of sacrifice. 
Discussing Mabo and Gallipoli as sites of national identity, Stephen Muecke concludes that 'Death is at the heart of the formation of the nation ... States can be set up as political entities, but they only become nations through the magical or spiritual agency of death'. ${ }^{21}$ Muecke is writing in the critical discourse of cultural analysis, where we might expect such connections and pronouncements. It is all the more arresting however to see similar claims in the editorial of the Sydney Morning Herald of 26 April 1922:

The Gallipoli campaign has been described as 'the most glorious failure in military history.' But was it a failure to Australia? It made us a nation. Was the price worth paying? Are not nations like individuals? If the nation is to be born, if the nation is to live, someone must die for it.

Journalistic rhetoric may have been more exuberant then than it is today, but this is still a dramatic statement. It is almost shocking to see it put so directly: if the nation is to live, someone must die for it. This is a myth model in discursive action. The logic of the argument is precisely what we find in Frazer's theories of succession and regeneration, where the King of the Wood gains his crown by killing the previous incumbent: life is born out of death. The whole key to understanding why Gallipoli became such an instant and powerful image of nationhood is recognising that all the pieces had already been put in place-except the great narrative of sacrifice. Gallipoli provided the requisite epic narrative to lend a mythic dimension to the story. It provided the folds needed to pleat history into the story of nationhood. Obeyesekere stresses that 'political and social conditions may either foster a particular myth model, rendering it dominant, or help in the invention of a new myth model based on older ones no longer apposite to the times'. ${ }^{22}$ The sort of nation Australia imagined itself to be, or to want to be, was thus very much influenced by the 'myth model' of the nation-state that was prevalent and fashionable in the modern period.

\section{- Repeating}

The early decades of the twentieth century constitute a period ne plus ultra when political and social conditions fostered the idea of the nation-state. Indeed, Hobsbawm calls the period the 'apogee of nationalism'. But what sort of nations were coming into being, and what were the myths that accompanied this burgeoning narrative of nationhood? Decolonisation had begun in the Americas a century before; the Ottoman Empire had been disintegrating in Europe and Asia Minor for decades; the Boer War had tested the frailty of European administration in Africa. Both the idea and the reality of nationalism were well established before 1914. So while the Great War provided the political 
mechanism for destroying old states and creating new ones, it did not, of itself, provide the motivation in the first place.

Indeed the Great War is increasingly being seen less as a discrete, unique phenomenon, but as part of much larger cycles and movements. Hobsbawm himself describes the world wars of the first half of the twentieth century as thirty or forty years of continuous conflict. ${ }^{23}$ And just as the warfare of 1914-18 becomes part of a longer, larger narrative, so too the nation-building that historically has been seen as a direct consequence of that particular conflict can properly be placed on a larger scale of time and events. Such a proposition then makes us ask whether the formation of nations circa 1918 is part of a larger story than simply the Great War. It questions whether events alone, however cataclysmic, can be the leaven for nationhood. It raises the possibility that if events are sufficiently similar to pre-existing paradigms of nation-forming, this can suggest the myth model of nationhood.

As is well known the whole notion of history as shaped by single events has been challenged by the Annales school of history. Lucien Febvre characterises events as simply the 'visible crust of history'-that is, prominent, but superficial. Jacques le Goff likewise attacks the 'illusions' and 'facilities' of event history (histoire événementielle). Reflecting on his own experience of growing up in the memory of the Great War and living through the subsequent warfare of the 1940s, le Goff argues that even on the world scale, wars do not create a significant 'break' in the course of history. And then there is Fernand Braudel, who sketches a theoretical apparatus for a new historical discourse that eschews the 'feats of princes' as merely the waves on the surface, when the real subject should be the deep currents of the powerful tides. ${ }^{24}$

As well as subverting the dominant role of events in history, Braudel questioned the understanding of time. Advocating the principle of la longue durée, Braudel proposed a distinction between individual time, social time and geographical time. It is only when we get beyond the event history of individual time that we can begin to see things according to la longue durée, to think in the social time of institutions or the geographical time of ecology. Employing these different epistemologies of time enabled Braudel to link (or suppress) disparate events and actors in the grand narrative of his subject, the Mediterranean world in the latter sixteenth century. ${ }^{25}$ Taking up Braudel's challenge, Tom Griffiths has written of the need to reconsider and 'reconfigure' Australian history in terms of la longue durée, or what he calls 'deep time'. For Griffiths, the emergence of deep time gives an entirely new dimension to current debates in Australia, debates about issues such as environment and population, and cultural identity and colonisation. $^{26}$ 
In terms of nationhood, the lessons of la longue durée are compelling. Nations do not come into being in the scale of the short term of individual time. Any given event, however significant, is always part of a larger cycle or series: "Each "current event" brings together movements of different origins, of a different rhythm'. ${ }^{27}$ Similarly then, nationness can be said to be an idea and a reality that came to prominence in the late nineteenth century, and had its apogee in the turmoil of thirty years of world war. But the conditions that engendered nationalism begin well before this, and the paradigms stretch back to antiquity. Moreover, at a metaphorical level, the rhetoric of nationalism and nationhood is to be found in symbols and narratives that have no specific origins, but exist in many forms and recur in many ages; that is to say, in myths. ${ }^{28}$

In this sense it is clear that while the Great War cannot be said to be the root cause of nationhood, it nevertheless provides the quintessential topoi in the narratives of nationhood: death and sacrifice. The poet Wilfred Owen was only too well aware of this, as his bitter appropriation of Horace demonstrates in 'Dulce et decorom est'. ${ }^{29}$ Another famous invocation of nationhood that Owen reworks is the story in Genesis of Abraham and Isaac. He takes the original message of trust and promise and turns it into one of betrayal and murder, so that Abraham slays his son, 'and half the seed of Europe, one by one. ${ }^{30}$ Apart from the savage inversion of the sacrificial covenant, the deeper irony is in the intertextual reference-for the purpose of the story is not just that the Lord spares Isaac's life, but that the obedient Abraham is rewarded with a nation: his descendants ('seed') will be 'as numerous as the stars in the sky and the grains of sand on the sea-shore'. ${ }^{31}$ This is surely one of the greatest poetic realisations of the idea of nation, the imagining of a fertile and enduring future. Not that Wilfred Owen saw it that way.

The sacrifice of the first-born son is a recurring motif in the Jewish and Christian bibles: Abraham offers up Isaac; the Pharaoh orders all male Hebrew babies to be thrown into the Nile; the first-born of Egypt are killed; King Herod schemes to capture the infant Jesus; God sacrifices his only son on the cross. Repetition is one of the most important tropes in these texts. The Torah frequently tells the same story twice in different redactions, just as the four gospels give multiple accounts of the same scenes from the life of Jesus. Narrative time thus constantly circles back upon itself. Similarly, while the lists of the ancestors and their ages mark the passing of time, the unreality of their supernatural life-spans injects considerable tension into the historical chronology. The theme of prophecy that binds the two testaments is another element in this overall temporal slippage, in which narrative time is stretched and folded, and historical time is condensed. Consider the following observation of Auerbach's: 
If an occurrence like the sacrifice of Isaac is interpreted as prefiguring the sacrifice of Christ, so that in the former the latter is as it were announced and promised and the latter 'fulfils' the former, then a connexion is established between the two events which are linked neither causally nor temporally. ${ }^{32}$

Auerbach describes this as an example of a 'simultaneity' of time. Elsewhere in the Exodus story we see a condensation of narrative time, what Robert Alter calls an 'illusion of simultaneity'. ${ }^{33}$ It is comparable to the 'messianic time' that Walter Benjamin describes in his 'Theses on the Philosophy of History', which places the past and future together in an instantaneous present. But Benjamin identifies another mode of temporality, which he styles a 'progression through homogenous, empty time'. ${ }^{34}$

It is this new ontology of reckoning time that Anderson sees in the development of nationalism, a moment when simultaneity is marked 'not by prefiguring and fulfilment, but by temporal coincidence, and measured by clock and calendar'. ${ }^{35}$ Such shifts in ontology are then distilled into the two literary forms that ushered in the era of nationalism: namely, the novel and newspaper, epitomised respectively by realism and by calendrical measurement. Edward Said questions Anderson's 'mistakenly linear periodizations', but such a model remains appealing to many, historiographers and literary historians alike. ${ }^{36}$ Anderson thus agrees with Auerbach that the biblical notion of simultaneity is 'wholly alien to our own'.

It is only alien to a positivist conception of time, however-time as a linear progression, time as the march of civilisation. In la longue durée, in deep time, the paradoxes of past and future are more easily reconcilable. Indeed, in mythic chronology, time can go forward or backward, or be flattened altogether in simultaneity. Repetition, at this level, thus becomes the key to reconfiguring our understanding of the events in individual time. In a realist temporality, repetition can be fortuitous or irrelevant; it is simply coincidence. But in a mythical temporality, repetition signifies inevitability, it carries the authority of destiny.

\section{- Pleating}

This collapsing of time is a key element in what might be called a 'chronotope of nationhood'. Bakhtin gives the name chronotope to the 'intrinsic connectedness of temporal and spatial relationships that are artistically expressed in literature'. ${ }^{37}$ In the literary artistic chronotope, writes Bakhtin, spatial and temporal are fused into a single, concrete whole: 'Time, as it were, thickens, takes on flesh, and becomes artistically visible; likewise, space becomes charged and responsive to the movements of time, plot and history'. ${ }^{38}$ Because of the interrelation of 'literature' and historiography, we can extend the 
chronotope's domain to historical poetics, where time and space are of the utmost importance. And in regard to Australia's nationhood, we can see that what we might call the 'Anzac chronotope' comprises a chronology of simultaneity, and a locus of elsewhere.

The temporal dimension in this chronotope of nationhood involves a chronological perspective that dismisses calendrical time, and collapses the past, present and future into a simultaneous 'now', what Benjamin calls Jetztseit. ${ }^{39}$ It shows that the Gallipoli nation is shot through with the same sort of mythic imagining that Auerbach saw in the biblical conception of time: 'The here and now is no longer merely a link in an earthly chain of events, it is simultaneously something which has always been, and will be fulfilled in the future'. ${ }^{40}$ Barthes sees myth having the same effect on history: 'Myth deprives the object of which it speaks of all History'. ${ }^{41}$ Barthes calls this the 'miraculous evaporation of history', where the object's origin can only be found in Eternity.

The spatial dimension (topos/locus) of the chronotope is 'somewhere else'; it is distant, in another place. This condition of spatial liminality echoes the rite of initiation (rites de marge), where an initiand is taken away to another place, and only returned to their family/society once the requisite rites have been performed. Liminality has an important function in narrative as well, where it is typical in romance genres for transformative action to take place in some separate place at some remove from the everyday (a forest, a desert, underground or overseas, for instance). In addition to its abstract value of otherness, the place of nationhood for Australia has a specific valency in its proximity to the 'cradle of civilisation' and sites of classical myth such as Greece and Troy. Equally important is that the action is played out on a European stage in front of an Old World audience, who witness the initiation of the debutante nation.

We see here the pleating of history in all its metaphorical implications. When a skirt is folded into pleats a number of things are achieved. First, parts that are originally separate come together; this is the collapsing of temporal distance, as past and future meet together in the present. Second, parts that were once visible are placed out of sight, hidden within the folds of the pleats; here is the displacing or forgetting of unwanted history. Third, the pleats create an impression of structure and order, as the creases and folds that are the ruptures of history are ironed into a smooth surface. Here is how the 'pile of wreckage' witnessed by Benjamin's angel of history is transformed into a narrative of destiny and fulfilment-the wreckage is simply swept under the carpet, or in this metaphor, hidden in the pleats.

It will be apparent that the temporality of the chronotope being proposed here is not the linear time which Anderson maintains is the midwife to modern nationalism, which historicises the nation and locates it firmly in time and space. Where Anderson sees nationhood as rooted in a thoroughly modern temporality, this other model disrupts 
linearity and rejects historicism. Logically then, the narrative of Australia's nationhood is contrary to that of the nations that figure in Anderson's thesis-in other words, Australia is a different kind of nation.

Every nation is unique of course, but for the purposes of these theoretical arguments Australia appears to stand apart. For example, at the time of Federation, Australia had fought no foreign wars and knew only one language; it was ethnically confident in its Britishness. As an island continent, there have never been common borders to dispute. More importantly, the whole nation only came into existence after the shifts in cultural conception that drive Anderson's thesis. Its polity was fabricated without a feudal hangover, its constitution was blended from the two most sophisticated democracies in the world.

In these terms Australia was and is an always-already modern nation. Unlike so many of the would-be nations described by Anderson and other theorists, white Australia had little historical matter of its own out of which to imagine a new future. Australia's history could be measured in decades, not in centuries. Its heritage was tallied not in dynasties, but across a mere brace of generations. Les Murray tersely captures this anxiety in his poem 'A Brief History': 'We are the Australians. Our history is short. ${ }^{42}$ For Murray, a reactionary republican, 'A short history gets you imperial scorn'. This nation craved an ancestral past, not a modern future. What Australia lacked was some cultural and historical baggage to call its own. It was not embarrassed by a medieval history, but in desperate need of one. There is no need to escape from a synchronous relation with the past; rather, this is exactly the type of temporal imagining the nation was searching for, a way of claiming an ancestral heritage without having to inflate the meagre and dubious details of the country's 'short history'.

The myth model embedded in the narrative of the Gallipoli nation is not that of modern Poland or Serbia, or other nations with long histories of heroic struggle against the suppression of their identity. Nor is it the model of Argentina or Mexico, of wresting independence in a war against a colonial overlord. The federation of the colonies was different too from the unification of Italy or Germany in the nineteenth century, for there was not the same sense of deep cultural destiny. In fact, the Australian scenario was in some ways closer to the fascist models that emerged as a consequence of the Great War: one that attempted to resurrect national pride by invoking a simultaneity of time and reaching back to the imperial glory of Rome; another that did the same by imagining the present as a constant for one thousand years of German Reich into the future. As Cassirer says, 'In myths, the nation's past is dramatized in such a way as to make its future destiny apparent'. ${ }^{43}$ The Gallipoli nation is a people trying to invent for themselves that very past, 
stretching back into almost-forgotten history, and through a similar collapsing of time, to imagine the same infinite future.

Here is the real key to Gallipoli. More than anything else the Anzac myth constructs a means of repressing the secrets of Australia's genesis. By wrenching the origin of the nation into the twentieth century, the invasion and colonisation are hidden from view. The Aboriginal population is conveniently forgotten. The convict stain is wiped clean. In this narrative there is no past, no chrysalis hiding unpalatable truths of a history that never was. The Australian nation is an imago bursting forth as if from nowhere, ready to fly upon the world stage. Such a construction adumbrates Barthes's dictum that 'what the world supplies to myth is a historical reality ... and what myth gives in return is a natural image of this reality'. ${ }^{44}$

But every theory of nationalism and nationhood argues the contrary-that nations are the end product of an already-established nationalism. Where then is the origin of the 'Australian nation'? Is it to be found in Edmund Barton's Federation slogan, 'A nation for a continent, and a continent for a nation'. Did it begin with Parkes's speech at Tenterfield? In the shearing sheds, or at Eureka? Was independence already nascent in the bruised pride of transported convicts? It is impossible to single out any individual or event or movement, for nations have no clearly identifiable conceptions or births. But wherever the origins are sought, the nationalism that created the Commonwealth existed well before Federation, and the nation that people suddenly see clearly in 1915 is new only in their sight.

The key to the Frazerian cycle is the dialectic between originality and repetition. Each year is new, but each season the same as the previous year. Each new king of the wood is another individual, but they all suffer the same fate. This oxymoron can be seen in Australia's pathology of identity: only by being different can one be noticed, but only by being the same can one be included. Although the Gallipoli nation purports to celebrate a distinctive character and identity, it betrays the paradox that nationhood has been achieved as per the old way, war and sacrifice — the nation is not so different after all. What other models might Australia have aspired to? Manning Clark held fast to a romanticised view of Australia as a truly new society, where democratic liberties would triumph over privilege and capital. But with the coming of the Great War, and Australia's desperate eagerness to participate, he concluded that the ideals of Australia had been 'cast to the winds'. ${ }^{45}$ The nation was just like any other, and would cleave to the old dead tree, never the young tree green. 
The narratives of the world are numberless, says Barthes-but we all tell the same stories. In the words of Horace, 'Mutato nomine de te fabula narratur' (Change the name and the story is told about you). ${ }^{46}$ With Gallipoli, Australia could at last tell the story it had waited for, never stopping to notice that it was only the subject's name that was different. Such is the pattern in the pleating of history.

MARTIN BALL is an honorary research fellow at the Australian Centre, University of Melbourne.

1. Voltaire, L’Ingénu, ch. 10; Alexis de Tocqueville, L'Ancien Régime, Michel Lévy Frères, Paris, 1856 p. 133; Dionysius, Ars Rhetorica, ch. 11, sect. 2 Sellar and Yeatman, 1066 and all that, London, Methuen, 1930, 'Compulsory Preface'.

2. Hayden White, Metahistory: The Historical Imagination in Nineteenth-century Europe, Baltimore, Johns Hopkins University Press, 1973, p. ix.

3. Michel de Certeau, 'The Historiographical Operation', in The Writing of History, New York, Columbia University Press, 1988, p. 55. The original French is 'Que fabrique l'historien, lorsqu'il "fail de l'histoire"?

4. Walter Benjamin, 'Theses on the Philosophy of History', in Illuminations, London, Fontana, sec. VII; GR Elton, The Practice of History, Sydney University Press, Sydney, 1967

5. Gilles Deleuze, The Fold: Leibniz and the Baroque, University of Minnesota Press, Minneapolis, 1993.

6. Madeleine L'Engle, A Wrinkle in Time, Farrar, Strauss \& Giroux, New York, 1988 [1962], pp. 72-3. Mrs Who's verb 'tesser' bears a close resemblance to 'tèssere', the Italian for 'weave'.

7. Henry Handel Richardson, The Fortunes of Richard Mahony: Australia Felix, Ringwood, Penguin, 1971 [1917], p. 1.

8. Wilfred Owen, 'Anthem for Doomed Youth', in J Stallworthy (ed.), The Complete Poems and Fragments of Wilfred Owen, London, Chatto \& Windus, 1983

9. Philip Mead, 'Death and Homework: The Origins of Narrative in The Fortunes of Richard Mahony', Australian Literary Studies, vol. 17, 1995, pp. 115-134.

10. Gananath Obeyesekere, The Apotheosis of Captain Cook: European Myth Making in the Pacific, Princeton University Press, 1992, p. 10.

11. Ernst Renan, 'What is a Nation?', in Homi Bhabha (ed.), Nation and Narration, Routledge, London, 1990, p. 9; Tom Nairn, The Break-up of Britain
New Left Books, London, 1977 p. 369; Eric

Hobsbawm, Nations and Nationalism since 1780 ,

ch. 1; Benedict Anderson, Imagined Communities, Verso, London, 2nd ed., 1991, p. 3.

12. Hobsbawn, p. 131

13. Anderson, p. 145

14. Henry Parkes, The Federal Government of Australasia: Speeches Delivered on Various Occasions, November 1889-May 1890, Sydney, 1890.

15. DH Lawrence, Kangaroo, Angus \& Robertson, Sydney, 1922 (corrected edition, 1923), p. 85 16. Anderson, p. 145

17. Anderson, p. 144

18. Bopal Balakrishnan, 'The National Imagination', New Left Review, no. 211, 1995, pp. 56-69.

19. Michael Howard, The Causes of War, Harvard University Press, Cambridge, 1983, p. 27.

20. Parkes The Federal Government of Australasia: Speeches Delivered on Various Occasions, November 1889-May 1890, Sydney, 1890.

21. Stephen Muecke, 'Australia, For Example', in Cassandra Pybus (ed.), Columbus' Blindness and Other Essays, University of Queensland Press, St Lucia, 1994, p. 14

22. Obeyesekere, p. 10.

23. Eric Hobsbawm, The Age of Extremes, Michael Joseph, London, 1994, p. 22

24. Lucian Febvre, Combats pour l'Histoire, Armand Colin, Paris, 1965, p. 62; Jacques Le Goff, 'LAppétit de l'Histoire', in Pierre Nora (ed.), Essais d'Egohistoire, Gallimard, Paris, 1987, p. 176; Fernand Braudel, La Méditerranée et la Monde Méditerranéen à l'Époque de Philippe II, Armand Colin, Paris, pp. 13-14. For an overview of the Annalistes and their many metaphors, see Philippe Carrard, Poetics of the New History, Johns Hopkins University Press, Baltimore, ch. 2.

25. Anderson makes the observation that Braudel's 1200-page history never mentions the massacre of St Bartholomew's Day (the event that Renan says 
all French citizens 'must have forgotten to remember'), and yet it occurred at the very midpoint of the period Braudel narrates. Imagined Communities, p. 205)

26. Tom Griffiths, 'Travelling in Deep Time: La Longue Durée in Australian History', Australian Humanities Review, 2000, <http://www.lib.latrobe.edu.au/ AHR >. Among other matters Griffiths considers the ecological and cultural practices of Aborigines, and asks 'Have settler Australians yet earned the right to travel in deep time in their own country?'

27. Fernand Braudel, 'History and the Social Sciences: La Longue Durée' in On History, Weidenfeld \& Nicolson, London, 1980 , p. 34.

28. Braudel, 'History and the Social Sciences', pp. $45-6$

29. For a discussion of how the rhetoric of Owen's poem has influenced reading of the batttle of the Nek at Gallipoli, see my 'Pro Patria Mori', Meanjin, vol. 63 , no. 3, 2004, pp. 3-12

30. Wilfred Owen, 'The Parable of the Old Men and the Young', in Stallworthy

31. Genesis 22:1-18

32. Erich Auerbach, Mimesis, Princeton University Press, 1953, p. 84
33. Robert Alter, The Art of Biblical Poetry, Basic Books, New York, 1985, p. 54.

34. Benjamin, sec. XIII.

35. Anderson, p. 24

36. Edward Said, Culture and Imperialism, Knopf, New York, 1993, p. 280

37. Mikail Bakhtin, 'Forms of Time and the Chronotope', in The Dialogic Imagination,

University of Texas Press, Austin, 1981, p. 84 Bakhtin's Russian word 'chronotop' is a simple compound combining the Greek words for time and space: chronos and topos.

38. Bakhtin, p. 84

39. Benjamin, sec. XIV

40. Auerbach, p. 64

41. Roland Barthes, 'Myth Today', in Mythologies, Noonday, New York, 1988, p. 151.

42. Les Murray, Subhuman Redneck Poems, Duffy \& Snellgrove, Sydney, 1996.

43. Ernst Cassirer, The Myth of the State, Yale University Press, New Haven, 1946

44. Barthes, p. 142.

45. Manning Clark, A History of Australia Melbourne University Press, Carlton, vol. 5, p. 426.

46. Horace, Satires, I, i, p. 69 